\title{
Epidemiology of gonorrhoea and syphilis in South Australia (1966-77)
}

\author{
DON JORGENSEN \\ From the Venereal Disease Control Centre, Department of Public Health, Adelaide, South Australia
}

SUMmaRY Data from the annual general report of the Venereal Disease Control Centre (VDCC) in a state with a population of approximately 1250000 people (in 1977), of whom about 1100000 live within 25 miles of the centre of Adelaide, the capital city, are presented.

\section{Introduction}

South Australia is the driest state in the driest continent in the world. Sparsely populated, the surface area is 380000 square miles compared with that of the United Kingdom, which is 95000 square miles. The aboriginal population living in the eight missions and other aboriginal centres are thought to number about 3000 (about $0.24 \%$ of the total), and they figure prominently in the epidemiology of syphilis because of the presence of endemic syphilis in these centres.

\section{Incidence of syphilis}

In 1966 legislation was passed requiring medical practitioners and laboratories dealing with syphilis or gonorrhoea to notify numbers of cases to the Central Board of Health. The incidence of reported syphilis has risen from $1 \cdot 4 / 100000$ in 1966 to $40 / 100000$ in 1976 (Table 1); this figure dropped to $28 / 100000$ in 1977. The rise in 1976 was almost entirely due to increased efficiency in collecting blood specimens from aboriginals in that year.

The overall incidence for Australia has dropped behind the South Australian figures since the early 1970s, not because South Australia has more cases of syphilis but because the figures are more accurate.

\section{Incidence of gonorrhoea}

Since 1966 the incidence of gonorrhoea has risen from $23 / 100000$ to $174 / 100000$ in 1974 and is now around 150/100 000; the steep rise in incidence

Address for reprints: D. Jorgensen, VD Control Centre, Department of Public Health, 275 North Terrace, Adelaide, S. Australia 5000

Received for publication 2 September 1978 since 1966 seems to have levelled out over the last four years (Table 2). There are, no doubt, two reasons for this increase: an actual increase in the number of cases and an increase in efficiency in collecting statistics. The overall incidence of 85/100000 in Australia in 1976 and 1977 shows

Table 1 Notification of cases of syphilis from 1966 to 1977. (Populations in 1977 of Australia and South Australia were $14 \frac{1}{4}$ million and $1 \frac{1}{4}$ million respectively)

\begin{tabular}{|c|c|c|c|c|}
\hline Year & $\begin{array}{l}\text { South } \\
\text { Australia }\end{array}$ & $\begin{array}{l}\text { Rate per } \\
1000000\end{array}$ & Austrzlia & $\begin{array}{l}\text { Rate per } \\
100000\end{array}$ \\
\hline 1966 & 15 & 1.4 & 1080 & $9 \cdot 3$ \\
\hline 1967 & 21 & 1.9 & 845 & 8.0 \\
\hline 1968 & 58 & $5 \cdot 2$ & 860 & $7 \cdot 1$ \\
\hline 1969 & 38 & $3 \cdot 3$ & 1072 & $8 \cdot 6$ \\
\hline 1970 & 74 & $6 \cdot 4$ & 952 & 7.9 \\
\hline 1971 & 122 & 10.4 & 1047 & $8 \cdot 3$ \\
\hline 1972 & 205 & $17 \cdot 0$ & 1215 & $9 \cdot 3$ \\
\hline 1973 & 178 & 15.0 & 1433 & 10.9 \\
\hline 1974 & 257 & $21 \cdot 5$ & 1864 & 13.9 \\
\hline 1975 & 309 & $25 \cdot 0$ & 2362 & 18.0 \\
\hline 1976 & 501 & 40.0 & 3110 & 23.0 \\
\hline 1977 & 360 & $28 \cdot 1$ & 3023 & $21 \cdot 5$ \\
\hline
\end{tabular}

Table 2 Notification of cases of gonorrhoea from 1966 to 1977

\begin{tabular}{lllll}
\hline Year & $\begin{array}{l}\text { South } \\
\text { Australia }\end{array}$ & $\begin{array}{l}\text { Rate per } \\
100000\end{array}$ & Australia & $\begin{array}{l}\text { Rate per } \\
100000\end{array}$ \\
\hline 1966 & 355 & 23 & 8553 & 74 \\
1967 & 599 & 51 & 9412 & 80 \\
1968 & 509 & 43 & 9763 & 79 \\
1969 & 703 & 61 & 9648 & 79 \\
1970 & 650 & 55 & 9558 & 76 \\
1971 & 817 & 70 & 10274 & 81 \\
1972 & 989 & 83 & 11017 & 85 \\
1973 & 1492 & 126 & 11357 & 85 \\
1974 & 2091 & 174 & 12524 & 95 \\
1975 & 2121 & 172 & 12511 & 93 \\
1976 & 1885 & 151 & 11526 & 85 \\
1977 & 1921 & 150 & 12024 & 85 \\
\hline
\end{tabular}


that our national figures do not reflect the prevalence of gonorrhoea in the country as a whole (Table 2).

It is not possible to estimate how many cases of urethral discharge are treated empirically, and these figures do not, therefore, enter the statistics; but there are, however, many cases in South Australia and, obviously, more in Australia as a whole.

\section{Epidemiological data of notified cases}

\section{AGE GROUPS}

For cases of gonorrhoea the predominant age group is 15-19 years in women and 20-24 years in men. These two groups were responsible for $68 \%$ of cases of gonorrhoea in 1977 (Table 3).

The age range for syphilis, on the other hand, is greater, but those figures include both active and inactive notified cases; most of the active syphilis occurs in the younger age groups (Table 3 ).

\section{MARITAL STATE}

In $1977,1577(80 \%)$ out of 1921 cases of gonorrhoea occurred in single people. The figures for syphilis were more evenly divided but include both active and inactive cases (Table 4).

SOURCES OF INFECTION

Friends or fiancés or casual contacts account for

Table 3 Notifications and incidence of gonorrhoea and syphilis by age and sex (1977)

\begin{tabular}{|c|c|c|c|c|c|c|}
\hline \multirow[b]{2}{*}{ Age (years) } & \multicolumn{3}{|c|}{ Gonorrhoea } & \multicolumn{3}{|c|}{ Syphilis } \\
\hline & Male & Female & Total & Male & Female & Total \\
\hline $0-9$ & 2 & 1 & 3 & & & \\
\hline $10-14$ & 1 & 15 & 16 & & 2 & 2 \\
\hline $15-19$ & 312 & 304 & 616 & 15 & 30 & 45 \\
\hline $20-24$ & 454 & 238 & 692 & 56 & 76 & 92 \\
\hline $25-29$ & 239 & 75 & 312 & 60 & 76 & 86 \\
\hline $30-39$ & 169 & 48 & 217 & 54 & 16 & 70 \\
\hline $40-49$ & 38 & 7 & 45 & 19 & 6 & 25 \\
\hline 50 and over & 15 & 5 & 20 & 27 & 13 & 40 \\
\hline Total (1977) & 1228 & 693 & 1921 & 231 & 129 & 360 \\
\hline Total (1976) & 1145 & 740 & 1885 & 299 & 202 & 510 \\
\hline Total (1975) & 1296 & 825 & 2121 & 164 & 140 & 304 \\
\hline
\end{tabular}

Table 4 Marital state of notified cases of gonorrhoea and syphilis

\begin{tabular}{|c|c|c|c|c|c|c|c|c|c|c|c|c|c|c|c|c|c|c|}
\hline \multirow[b]{3}{*}{ Marital state } & \multicolumn{9}{|c|}{ Gonorrhoea } & \multicolumn{9}{|c|}{ Syphilis } \\
\hline & \multicolumn{3}{|l|}{ Male } & \multicolumn{3}{|c|}{ Female } & \multicolumn{3}{|l|}{ Total } & \multicolumn{3}{|l|}{ Male } & \multicolumn{3}{|c|}{ Female } & \multicolumn{3}{|l|}{ Total } \\
\hline & 1975 & 1976 & 1977 & 1975 & 1976 & 1977 & 1975 & 1976 & 1977 & 1975 & 1976 & 1977 & 1975 & 1976 & 1977 & 1975 & 1976 & 1977 \\
\hline Single & 1051 & 886 & 1045 & 657 & 546 & 532 & 1708 & 1432 & 1577 & 87 & 122 & 141 & 54 & 76 & 72 & 141 & 198 & 213 \\
\hline Married & 158 & 165 & 122 & 92 & 93 & 85 & 250 & 258 & 207 & 33 & 120 & 79 & 47 & 103 & 53 & 80 & 223 & 132 \\
\hline Defacto & 19 & 22 & 9 & 16 & 26 & 12 & 35 & 48 & 21 & & 4 & & 1 & 3 & & 1 & 7 & \\
\hline Widowed & 3 & 1 & 1 & 7 & 2 & & 10 & 3 & 1 & & & & & 1 & 1 & & 1 & 1 \\
\hline Divorced & 16 & 8 & 3 & 10 & 18 & 19 & 26 & 26 & 22 & & 1 & 1 & & 1 & & & 2 & 1 \\
\hline Separated & 42 & 58 & 45 & 42 & 53 & 45 & 84 & 111 & 90 & 3 & 2 & 2 & 1 & 2 & 2 & 4 & 4 & 4 \\
\hline Unknown & 7 & 5 & 3 & 1 & 2 & & 8 & 7 & 3 & 41 & 50 & 8 & 37 & 16 & 1 & 78 & 66 & 9 \\
\hline Total & 1296 & 1145 & 1228 & 825 & 740 & 693 & 2121 & 1885 & 1921 & 164 & 299 & 231 & 140 & 202 & 129 & 304 & 501 & 360 \\
\hline
\end{tabular}

Table 5 Source of infection of notified cases of gonorrhoea and syphilis

\begin{tabular}{|c|c|c|c|c|c|c|c|c|c|c|c|c|c|c|c|c|c|c|}
\hline \multirow[b]{3}{*}{ Contact } & \multicolumn{9}{|c|}{ Gonorrhoea } & \multicolumn{9}{|c|}{ Syphilis } \\
\hline & \multicolumn{3}{|c|}{ Male } & \multicolumn{3}{|c|}{ Female } & \multicolumn{3}{|l|}{ Total } & \multicolumn{3}{|l|}{ Male } & \multicolumn{3}{|c|}{ Female } & \multicolumn{3}{|l|}{ Total } \\
\hline & 1975 & 1976 & 1977 & 1975 & 1976 & 1977 & 1975 & 1976 & 1977 & 1975 & 1976 & 1977 & 1975 & 1976 & 1977 & 1975 & 1976 & 1977 \\
\hline Marital partner & 32 & 41 & 17 & 70 & 54 & 40 & 102 & 95 & 57 & 3 & 3 & 1 & 9 & 5 & 5 & 12 & 8 & 6 \\
\hline Defacto partner & 15 & 19 & 9 & 17 & 20 & 7 & 32 & 39 & 16 & 1 & 2 & & 1 & 2 & & 2 & 4 & \\
\hline Friend/fiancé & 356 & 294 & 341 & 319 & 289 & 326 & 675 & 583 & 667 & 3 & 11 & 14 & 5 & 10 & 5 & 8 & 21 & 19 \\
\hline Casual contact & 741 & 589 & 560 & 394 & 317 & 257 & 1135 & 906 & 817 & 45 & 42 & 30 & 19 & 16 & 7 & 64 & 58 & 37 \\
\hline Prostitute & 24 & 39 & 38 & & & & 24 & 39 & 38 & 1 & 4 & & & & & 1 & 4 & \\
\hline Homosexual & 58 & 60 & 145 & & & & 38 & 60 & 145 & 6 & 20 & 17 & & & & 6 & 20 & 17 \\
\hline Mother & 1 & 4 & 2 & & 2 & & 1 & 3 & 2 & & 1 & & & & & & 1 & \\
\hline Unknown & & 102 & 116 & & 58 & 63 & & 160 & 179 & 116 & 216 & 169 & 100 & 169 & 112 & 216 & 385 & 281 \\
\hline Total & 1227 & 1145 & 1228 & 800 & 740 & 693 & 2027 & 1885 & 1921 & 175 & 299 & 231 & 134 & 202 & 129 & 309 & 501 & 360 \\
\hline
\end{tabular}


$77 \%$ of sources of infection for gonorrhoea and $21 \%$ for syphilis; unknown sources of the latter account for $78 \%$ of cases (Table 5). This high unknown factor is due to the difficulties of contacttracing in the aboriginal population. A feature of both gonorrhoea and syphilis is the substantial number of homosexuals affected $-8 \%$ overall for gonorrhoea $(12 \%$ in males) and $5 \%$ overall for syphilis ( $8 \%$ in males).

\section{USUAL RESIDENCE}

Eighty-eight per cent of patients with gonorrhoea lived within 25 miles of the centre of Adelaide. Patients with syphilis were more or less evenly distributed, because of the aboriginal missions (Table 6).

\section{COUNTRY OF ORIGIN}

Table 7 shows only the numbers of cases from each country of origin. The percentages of the total population for the groups is not known. The aboriginal population accounted for $41 \%$ of cases of reported syphilis in 1977.

\section{OCCUPATION}

The highest number of notifications came from the less skilled and unemployed members of the community (Table 8); the actual percentages in the groups are not known. Among the cases of gonorrhoea $2.5 \%$ gave their occupation as prostitution.

\section{Notification of cases of syphilis by stage of disease}

In Table 9 notifications of cases of syphilis have been subdivided into stages of the disease in aboriginal missions (in brackets) and in the general population. These are difficult figures to extract but they do show trends. For the aboriginals it is not possible to give figures for primary and secondary syphilis because of the lack of clinical details.

Diagnosis is made by consultation between the serologist and the venereologist at the central laboratory, at the Institute of Medical and Veterinary Science, on the results of the serological tests. The nursing sisters, who live on the missions, are then given instructions by the venereologist on the treatment required. In the general population the prevalence of primary or early active syphilis is greater in men than in women and this agrees with experience in most countries.

Aboriginals living on reserves $(0.24 \%$ of the total population) were responsible for $149(41 \%)$ of 360 cases of syphilis notified in 1977.

\section{Sources of notified cases}

The VDCC notified $1142(60 \%)$ of 1921 cases of gonorrhoea and $186(52 \%)$ of 360 cases of syphilis, including cases from the out-back and aboriginals (Table 10). Until recently South Australia had the

Table 6 Usual residence of notified cases of gonorrhoea and syphilis

\begin{tabular}{|c|c|c|c|c|c|c|c|c|c|c|c|c|c|c|c|c|c|c|}
\hline \multirow[b]{3}{*}{ Residence } & \multicolumn{9}{|c|}{ Gonorrhoea } & \multicolumn{9}{|c|}{ Syphilis } \\
\hline & \multicolumn{3}{|l|}{ Male } & \multicolumn{3}{|c|}{ Female } & \multicolumn{3}{|l|}{ Total } & \multicolumn{3}{|l|}{ Male } & \multicolumn{3}{|c|}{ Female } & \multicolumn{3}{|l|}{ Total } \\
\hline & 1975 & 1976 & 1977 & 1975 & 1976 & 1977 & 1975 & 1976 & 1977 & 1975 & 1976 & 1977 & 1975 & 1976 & 1977 & 1975 & 1976 & 1977 \\
\hline Metropolitan & 1122 & 968 & 1072 & 783 & 693 & 632 & 1905 & 1661 & 1704 & 80 & 132 & 142 & 55 & 70 & 52 & 135 & 204 & 194 \\
\hline Country & 154 & 162 & 144 & 39 & 43 & 58 & 193 & 205 & 202 & 78 & 161 & 87 & 85 & 131 & 76 & 163 & 292 & 163 \\
\hline Interstate & 9 & 12 & 10 & 3 & 4 & 3 & 12 & 16 & 13 & 1 & 1 & 1 & & 1 & 1 & 1 & 2 & 2 \\
\hline Overseas & 11 & 3 & 2 & & & & 11 & 3 & 2 & 5 & 3 & 1 & & & & 5 & 3 & 1 \\
\hline Total & 1296 & 1145 & 1228 & 825 & 740 & 693 & 2121 & 1885 & 1921 & 164 & 299 & 281 & 140 & 202 & 129 & 304 & 501 & 360 \\
\hline
\end{tabular}

Table 7 Country of origin of notified cases of gonorrhoea and syphilis

\begin{tabular}{|c|c|c|c|c|c|c|c|c|c|c|c|c|c|c|c|c|c|c|}
\hline \multirow[b]{3}{*}{ Country of origin } & \multicolumn{9}{|c|}{ Gonorrhoea } & \multicolumn{9}{|c|}{ Syphilis } \\
\hline & \multicolumn{3}{|l|}{ Male } & \multicolumn{3}{|c|}{ Female } & \multicolumn{3}{|l|}{ Total } & \multicolumn{3}{|l|}{ Male } & \multicolumn{3}{|c|}{ Female } & \multicolumn{3}{|l|}{ Total } \\
\hline & 1975 & 1976 & 1977 & 1975 & 1976 & 1977 & 1975 & 1976 & 1977 & 1975 & 1976 & 1977 & 1975 & 1976 & 1977 & 1975 & 1976 & 1977 \\
\hline Australia & 888 & 761 & 915 & 683 & 622 & 605 & 1571 & 1383 & 1520 & 73 & 121 & 109 & 49 & 58 & 46 & 122 & 179 & 155 \\
\hline Aboriginals & 108 & 106 & 54 & 35 & 36 & 20 & 143 & 142 & 74 & 64 & 148 & 72 & 77 & 132 & 77 & 141 & 280 & 149 \\
\hline United Kingdom & 94 & 77 & 87 & 57 & 38 & 32 & 151 & 115 & 119 & 3 & 4 & 5 & & 1 & 1 & 3 & 5 & 6 \\
\hline \multicolumn{19}{|l|}{ Mediterranean } \\
\hline Europe & 115 & 123 & 96 & 26 & 21 & 19 & 141 & 144 & 115 & 12 & 6 & 13 & 6 & 3 & 2 & 18 & 9 & 15 \\
\hline Other Europe & 65 & 57 & 55 & 15 & 22 & 15 & 80 & 79 & 70 & 10 & 11 & 5 & 5 & 8 & 2 & 15 & 19 & 7 \\
\hline Asia & 23 & 10 & 15 & 5 & 1 & 2 & 28 & 11 & 17 & 2 & 6 & 27 & & & 1 & 2 & 6 & 28 \\
\hline \multicolumn{19}{|l|}{ America } \\
\hline Other & 3 & 11 & 6 & 4 & & & 7 & 11 & 6 & & 3 & & 3 & & & 3 & 3 & \\
\hline Total & 1296 & 1145 & 1228 & 825 & 740 & 693 & 2121 & 1885 & 1921 & 164 & 299 & 231 & 140 & 202 & 129 & 304 & 501 & 360 \\
\hline
\end{tabular}


enviable position whereby syphilis serum antibody tests, other than reagin screening tests, were done in one laboratory, at the Institute of Medical and Veterinary Science, which resulted in a very accurate notification system together with standard methods and efficient control in serological tests. Accurate and consistent reporting of serological test results and accurate record-keeping of the serological history of syphilitic patients were possible. Now that syphilis serological tests are carried out in various other laboratories this position has altered, the main reasons being the difficulties in keeping the syphilis registry up to date and the differing laboratory standards.

TYPES OF CONTACTS

In addition to friends or fiancés or casual contacts, a high number of sexual contacts are homosexual, $244(15 \%)$ of 1606 cases with gonorrhoea and 29 (31\%) of 94 cases of syphilis (Table 11).

CONTACT-TRACING

In 1977, of 2570 contacts of gonorrhoea $842(32 \%)$ were not sought, mainly because of insufficient

Table 8 Occupation of notified cases of gonorrhoea and syphilis

\begin{tabular}{|c|c|c|c|c|c|c|c|c|c|c|c|c|}
\hline \multirow[b]{3}{*}{ Occupation } & \multicolumn{6}{|c|}{ Gonorrhoea } & \multicolumn{6}{|c|}{ Syphilis } \\
\hline & \multicolumn{2}{|l|}{ Male } & \multicolumn{2}{|c|}{ Female } & \multicolumn{2}{|l|}{ Total } & \multicolumn{2}{|l|}{ Male } & \multicolumn{2}{|c|}{ Female } & \multicolumn{2}{|l|}{ Total } \\
\hline & 1976 & 1977 & 1976 & 1977 & 1976 & 1977 & 1976 & 1977 & 1976 & 1977 & 1976 & 1977 \\
\hline Rural & & 41 & & 3 & & 44 & & 11 & & & & 11 \\
\hline Artist/entertainer & & 37 & & 6 & & 43 & & 1 & & & & 1 \\
\hline Professional & 14 & 16 & 4 & & 18 & 16 & & 2 & & & & 2 \\
\hline Technical & & 15 & & 3 & & 18 & & & & & & \\
\hline Skilled & 168 & 176 & 13 & 14 & 181 & 190 & 6 & 9 & & & 6 & 9 \\
\hline Apprentice & 13 & 31 & & 2 & 13 & 33 & 1 & & & & 1 & \\
\hline Semi-skilled & 140 & 84 & 23 & 21 & 163 & 105 & 3 & 6 & 2 & & 5 & 6 \\
\hline Unskilled & 242 & 211 & 13 & 18 & 255 & 229 & 1 & 45 & 1 & 7 & 2 & 52 \\
\hline Clerical & 121 & 143 & 188 & 134 & 309 & 277 & 21 & 18 & 11 & 6 & 32 & 24 \\
\hline Sales & 78 & 98 & 49 & 67 & 127 & 165 & 7 & 17 & 4 & 1 & 11 & 18 \\
\hline Maritime & & & & & & & & & & & & \\
\hline Student $\left\{\begin{array}{l}\text { Secondary } \\
\text { Tertiary }\end{array}\right.$ & 55 & 55 & 80 & 82 & 135 & 137 & 4 & 5 & 2 & 2 & 6 & 7 \\
\hline Nursing & 7 & 11 & 47 & 38 & 54 & 49 & 1 & & 1 & & 2 & \\
\hline Armed forces & 8 & 14 & & 1 & 8 & 15 & & 5 & 1 & & 1 & 5 \\
\hline Home duties & & & 120 & 115 & 120 & 115 & & & 52 & 39 & 52 & 39 \\
\hline Prostitution & & & 48 & 47 & 48 & 47 & & & 2 & 4 & 2 & 4 \\
\hline Retired & 4 & 2 & 19 & 21 & 23 & 23 & & 27 & 14 & 14 & 14 & 41 \\
\hline Unemployed/unknown & 121 & $10 \overline{8}$ & 81 & 72 & 202 & 180 & 245 & 76 & 111 & 56 & 356 & 132 \\
\hline Teaching & 6 & 20 & 7 & 7 & 13 & 27 & 3 & 3 & & & 3 & 3 \\
\hline Transport & 68 & 72 & 4 & 6 & 72 & 78 & & 3 & & & & 3 \\
\hline Service worker & 50 & 49 & 41 & 31 & 91 & 80 & & & 1 & & 1 & \\
\hline Total & 1145 & 1228 & 740 & 693 & 1885 & 1921 & 299 & 231 & 202 & 129 & 501 & 360 \\
\hline
\end{tabular}

Table 9 Number of cases of syphilis by stage of disease (figures for aboriginals in brackets)

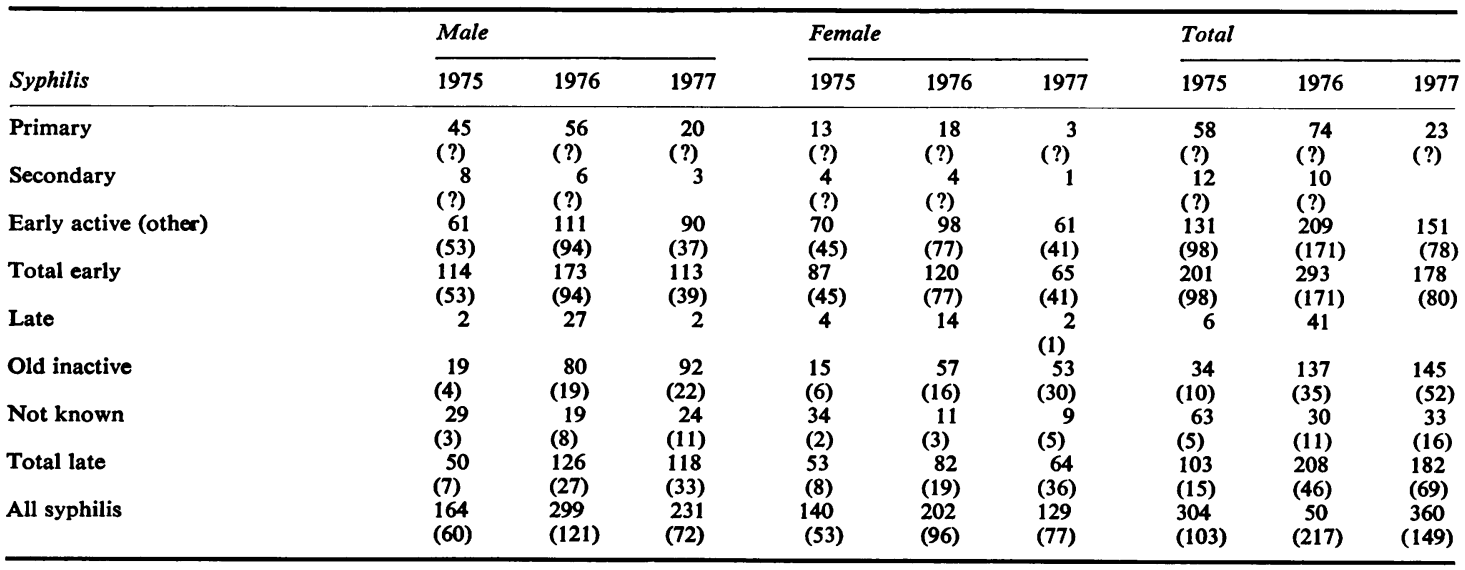


information. Of 1728 contacts sought, 1431 (82\%) were found; of 1431 found, $929(65 \%)$ were infected (Table 12). In 1977, of 120 contacts of syphilis 54 $(45 \%)$ were not sought; of 66 contacts sought, 59 $(90 \%)$ were found; and, of 59 contacts found, 26 $(44 \%)$ were infected.

The ratio of male-to-female cases of gonorrhoea was $2: 1$ compared with $1 \cdot 5: 1$ in 1976 . This ratio indicates the efficiency of contact-tracing methods, the ratio falling as efficiency increases.

\section{NOTIFICATION BY PRIVATE DOCTORS}

Tables 13a and 13b show a static position as regards notifications of cases of gonorrhoea and syphilis by private practitioners, which may not change much under present conditions. Two areas of effort which may improve notifications are: (1) increased efforts to show undergraduates and graduates the reasons for, and importance of, early notification; and (2) an easier method of notification, namely, a simple notification form attached to an addressed, pre-paid envelope marked private and confidential to be used by all private practitioners and laboratories.
ATTENDANCES AT THE VENEREAL DISEASE CONTROL CENTRE

An increase from 12674 to 14204 (12\% increase) patients occurred from 1976 to 1977 (Table 14); this is an increase in the daily average from 50 to 56 cases (12\% increase), and means that from 30 to 90 patients were seen each day. With the present staffing levels medical officers have difficulty in maintaining adequate standards.

\section{GONORRHOEA}

Of 1738 notifications from the metropolitan area $1102(63 \%)$ were seen at the VDCC (Table 15).

\section{NON-SPECIFIC URETHRITIS}

Non-specific urethritis is not readily distinguishable from gonorrhoea and other causes of urethritis in men without laboratory investigation, and although not a notifiable disease it is included in statistics from the UK and other countries. The total number of cases of non-specific urethritis seen at the VDCC in 1976 and 1977 are compared with that of male cases of gonorrhoea in Table 15.

Table 10 Sources of notifications for gonorrhoea and syphilis

\begin{tabular}{|c|c|c|c|c|c|c|c|c|c|c|c|c|c|c|c|c|c|c|}
\hline & \multicolumn{9}{|c|}{ Gonorrhoea } & \multicolumn{9}{|c|}{ Syphilis } \\
\hline & \multicolumn{3}{|l|}{ Male } & \multicolumn{3}{|c|}{ Female } & \multicolumn{3}{|l|}{ Total } & \multicolumn{3}{|l|}{ Male } & \multicolumn{3}{|c|}{ Female } & \multicolumn{3}{|l|}{ Total } \\
\hline & 1975 & 1976 & 1977 & 1975 & 1976 & 1977 & 1975 & 1976 & 1977 & 1975 & 1976 & 1977 & 1975 & 1976 & 1977 & 1975 & 1976 & 1977 \\
\hline $\begin{array}{l}\text { Private doctors } \\
\text { RAH and VDCC }\end{array}$ & 475 & 414 & 407 & 214 & 228 & 197 & 689 & 642 & 604 & 38 & 93 & 87 & 37 & 59 & 45 & 75 & 152 & 132 \\
\hline clinics & 691 & 694 & 709 & 520 & 434 & 433 & 1211 & 1038 & 1142 & 32 & 44 & 76 & 21 & 18 & 11 & 53 & 62 & 87 \\
\hline RAH other & 2 & 6 & 4 & 18 & 22 & 14 & 20 & 28 & 18 & 6 & 11 & 3 & 7 & 7 & 7 & 13 & 18 & 10 \\
\hline QEH & 20 & 16 & 17 & 36 & 18 & 28 & 56 & 34 & 45 & 7 & 5 & 4 & 4 & 9 & 8 & 11 & 14 & 12 \\
\hline QVH & & & & 9 & 8 & 6 & 9 & 8 & 6 & & & & 2 & 1 & 2 & 2 & 1 & 2 \\
\hline Port Adelaide clinic & 93 & 90 & 80 & 11 & 24 & 10 & 104 & 114 & 90 & 10 & 6 & 6 & & 2 & & 10 & 8 & 6 \\
\hline Armed forces & 1 & & 1 & & & & 1 & & 1 & & & & & & & & & \\
\hline Prisons & 1 & & 1 & 1 & & & & & & & & & & & & & & \\
\hline Outback RFDS, & & & & & & & & & & & & & & & & & & \\
\hline AIM etc. & 1 & 2 & & & & & 1 & 2 & & 58 & 129 & 47 & 59 & 103 & 52 & 117 & 232 & 99 \\
\hline Other & 12 & 13 & 9 & 16 & 6 & 5 & 28 & 19 & 14 & 13 & 11 & 8 & 10 & 3 & 4 & 23 & 14 & 12 \\
\hline Total & 1296 & 1145 & 1228 & 825 & 740 & 693 & 2121 & 1885 & 1921 & 164 & 202 & 129 & 140 & 202 & 129 & 304 & 501 & 360 \\
\hline
\end{tabular}

Table 11 Types of contacts noted (other than aboriginals in reserves)

\begin{tabular}{|c|c|c|c|c|c|c|c|c|c|c|c|c|c|c|c|c|c|c|}
\hline \multirow[b]{3}{*}{ Contacts } & \multicolumn{9}{|c|}{ Gonorrhoea } & \multicolumn{9}{|c|}{ Syphilis } \\
\hline & \multicolumn{3}{|l|}{ Male } & \multicolumn{3}{|c|}{ Female } & \multicolumn{3}{|l|}{ Total } & \multicolumn{3}{|l|}{ Male } & \multicolumn{3}{|c|}{ Female } & \multicolumn{3}{|l|}{ Total } \\
\hline & 1975 & 1976 & 1977 & 1975 & 1976 & 1977 & 1975 & 1976 & 1977 & 1975 & 1976 & 1977 & 1975 & 1976 & 1977 & 1975 & 1976 & 1977 \\
\hline Casual & 850 & 676 & 662 & 620 & 549 & 397 & 1470 & 1216 & 1059 & 52 & 45 & 38 & 23 & 32 & 12 & 75 & 77 & 50 \\
\hline Marital partners & 107 & 114 & 77 & 85 & 75 & 60 & 192 & 189 & 137 & 9 & 6 & 3 & 9 & 6 & 5 & 18 & 12 & 8 \\
\hline Defacto partners & 24 & 27 & 10 & 23 & 31 & 12 & 47 & 58 & 22 & 1 & 4 & 1 & 1 & 3 & & 2 & 7 & 1 \\
\hline Friend/fiancé & 630 & 501 & 571 & 486 & 506 & 531 & 1116 & 1007 & 1102 & 10 & 26 & 23 & 6 & 19 & 9 & 16 & 45 & 32 \\
\hline Homosexual & 97 & 109 & 244 & & & & 97 & 109 & 244 & 11 & 62 & 29 & & & & 11 & 62 & 29 \\
\hline Prostitute & 26 & 41 & 40 & & & & 26 & 41 & 40 & 1 & 4 & & & & & 1 & 4 & \\
\hline Mother & 1 & 1 & 2 & & 2 & & 1 & 3 & 2 & & 1 & & & & & & 1 & \\
\hline Total & 1735 & 1469 & 1606 & 214 & 1154 & 1000 & 2949 & 2623 & 2606 & 84 & 148 & 94 & 39 & 60 & 26 & 123 & 208 & 120 \\
\hline
\end{tabular}


Table 12 Contact-tracing

\begin{tabular}{|c|c|c|c|c|c|c|c|c|c|c|c|c|c|c|c|c|}
\hline \multirow[b]{4}{*}{ No. of contacts } & \multicolumn{8}{|c|}{ Gonorrhoea } & \multicolumn{8}{|c|}{ Syphilis } \\
\hline & \multicolumn{4}{|c|}{ Contacts of male cases } & \multirow{2}{*}{\multicolumn{2}{|c|}{$\begin{array}{l}\text { Contacts of } \\
\text { Female cases } \\
\text { Male }\end{array}$}} & \multirow{2}{*}{\multicolumn{2}{|c|}{ Total }} & \multicolumn{4}{|c|}{ Contacts of male cases } & \multicolumn{2}{|c|}{$\begin{array}{l}\text { Contacts of } \\
\text { Female cases }\end{array}$} & & \\
\hline & \multicolumn{2}{|c|}{ Female } & \multicolumn{2}{|l|}{ Male } & & & & & \multicolumn{2}{|c|}{ Female } & \multicolumn{2}{|l|}{ Male } & \multicolumn{2}{|l|}{ Male } & \multicolumn{2}{|l|}{ Total } \\
\hline & 1976 & 1977 & 1976 & 1977 & 1976 & 1977 & 1976 & 1977 & 1976 & 1977 & 1976 & 1977 & 1976 & 1977 & 1976 & 1977 \\
\hline $\begin{array}{l}\text { Noted } \\
\text { Not sought } \\
\text { Sought not found } \\
\text { Found } \\
\text { Diagnosed as infected } \\
\text { Treated epidemiologically }\end{array}$ & $\begin{array}{r}1360 \\
458 \\
207 \\
695 \\
404 \\
270\end{array}$ & $\begin{array}{r}1362 \\
449 \\
202 \\
711 \\
416 \\
141\end{array}$ & $\begin{array}{r}109 \\
45 \\
15 \\
49 \\
28 \\
20\end{array}$ & $\begin{array}{r}244 \\
70 \\
53 \\
121 \\
87 \\
19\end{array}$ & $\begin{array}{r}1154 \\
504 \\
83 \\
567 \\
423 \\
107\end{array}$ & $\begin{array}{r}1000 \\
323 \\
78 \\
599 \\
426 \\
104\end{array}$ & $\begin{array}{r}2623 \\
1007 \\
305 \\
1311 \\
855 \\
397\end{array}$ & $\begin{array}{r}2570 \\
842 \\
333 \\
1431 \\
929 \\
264\end{array}$ & $\begin{array}{l}86 \\
27 \\
18 \\
41 \\
22 \\
13\end{array}$ & $\begin{array}{r}65 \\
33 \\
5 \\
27 \\
11 \\
6\end{array}$ & $\begin{array}{r}62 \\
32 \\
8 \\
22 \\
5 \\
5\end{array}$ & $\begin{array}{r}19 \\
9 \\
4\end{array}$ & $\begin{array}{r}60 \\
14 \\
8 \\
38 \\
26 \\
5\end{array}$ & $\begin{array}{r}26 \\
11 \\
2 \\
13 \\
6 \\
2\end{array}$ & $\begin{array}{r}208 \\
73 \\
34 \\
101 \\
53 \\
23\end{array}$ & $\begin{array}{r}120 \\
54 \\
7 \\
59 \\
26 \\
12\end{array}$ \\
\hline
\end{tabular}

Table 13a Number of private doctors notifying cases of gonorrhoea or syphilis or both (numbers given in brackets refer to doctors notifying cases for the first time)

\begin{tabular}{|c|c|c|c|c|c|}
\hline \multirow[b]{2}{*}{ Year } & \multicolumn{2}{|c|}{ Area of practice } & \multirow[b]{2}{*}{ Total } & \multirow{2}{*}{$\begin{array}{l}\text { No. of Doctors } \\
\text { previously involved* }\end{array}$} & \multirow[b]{2}{*}{ PMS Doctors $\dagger$} \\
\hline & Metropolitan & Country & & & \\
\hline $\begin{array}{l}1966 \\
1967 \\
1968 \\
1969 \\
1970 \\
1971 \\
1972 \\
1973 \\
1974 \\
1975 \\
1976 \\
1977\end{array}$ & $\begin{array}{l}10 \\
51 \\
121 \\
140 \\
134 \\
185(52) \\
164(79) \\
225(141) \\
293(96) \\
270(85) \\
284(90) \\
279(84)\end{array}$ & $\begin{array}{l}7 \\
28 \\
38 \\
39 \\
38 \\
57(31) \\
69(35) \\
60(17) \\
72(22) \\
73(29) \\
69(21) \\
71(19)\end{array}$ & $\begin{array}{l}17 \\
79 \\
159 \\
179 \\
172 \\
215(83) \\
233(114) \\
285(158) \\
365(118) \\
343(114) \\
353(111) \\
350(103)\end{array}$ & $\begin{array}{l}\text { NA } \\
\text { NA } \\
131 \\
191 \\
215 \\
311 \\
245 \\
221 \\
241 \\
230 \\
235\end{array}$ & $\begin{array}{l}560 \\
580 \\
594 \\
615 \\
623 \\
638 \\
658 \\
690 \\
700 \\
700 \\
700\end{array}$ \\
\hline
\end{tabular}

* Doctors who have notified cases previously but not in the particular year †Doctors on Pensioner Medical Service Register at June 301977

NA not applicable

Table 13b Number of cases of gonorrhoea and syphilis notified by general practitioners

\begin{tabular}{llllll}
\hline & \multicolumn{3}{l}{ Gonorrhoea } & & \multicolumn{2}{l}{ Syphilis } \\
\cline { 2 - 3 } \cline { 5 - 6 } Year & Males & Females & & Males & Females \\
\hline 1975 & 475 & 214 & 38 & 37 \\
1976 & 414 & 228 & 93 & 59 \\
1977 & 407 & 197 & 87 & 45 \\
\hline
\end{tabular}

Table 14 Number of cases seen at the Venereal Diseases Control Centre in 1977 (figures for 1976 are given in brackets)

\begin{tabular}{|c|c|c|c|c|c|c|c|c|c|c|c|c|c|c|}
\hline & Jan. & Feb. & Mar. & Apr. & May & Jun. & Jul. & Aug. & Sep. & Oct. & Nov. & Dec. & Total & \\
\hline \multicolumn{15}{|l|}{ Male patients } \\
\hline Total & 678 & 858 & 748 & 610 & 718 & 656 & 598 & 601 & 869 & 769 & 838 & 662 & 8605 & (7507) \\
\hline Average/day & 35 & 43 & 33 & 34 & 34 & 31 & 28 & 26 & 40 & 38 & 38 & 33 & $34 \cdot 4$ & $(29 \cdot 8)$ \\
\hline New patients/episodes & 378 & 426 & 366 & 311 & 365 & 327 & 289 & 354 & 451 & 380 & 418 & 349 & 4414 & (3884) \\
\hline Average/day & 20 & 21 & 16 & 17 & 17 & 16 & 14 & 15 & 21 & 19 & 19 & 18 & $17 \cdot 7$ & $(15 \cdot 5)$ \\
\hline \multicolumn{15}{|l|}{ Female patients } \\
\hline Total & 405 & 503 & 512 & 426 & 495 & 495 & 408 & 518 & 522 & 463 & 523 & 329 & 5599 & (5167) \\
\hline Average/day & 21 & 25 & 22 & 24 & 24 & 24 & 19 & 23 & 24 & 23 & 24 & 17 & $22 \cdot 5$ & $(20 \cdot 4)$ \\
\hline Average/day & 10 & 11 & 8 & 9 & 9 & 8 & 8 & 9 & 11 & 10 & 9 & 7 & $9 \cdot 0$ & $(8 \cdot 5)$ \\
\hline \multicolumn{15}{|l|}{ Total no. of patients } \\
\hline Total & 1083 & 1361 & 1260 & 1036 & 1213 & 1151 & 1006 & 1119 & 1391 & 1232 & 1361 & 991 & 14204 & (12 674) \\
\hline Average/day & 56 & 64 & 55 & 58 & 58 & 55 & 47 & 49 & 64 & 61 & 62 & 50 & $56 \cdot 5$ & $(50 \cdot 2)$ \\
\hline New patients/episodes & 565 & 651 & 552 & 474 & 557 & 490 & 457 & 560 & 685 & 584 & 620 & 486 & 6681 & (6052) \\
\hline Average/day & 30 & 32 & 24 & 26 & 26 & 24 & 22 & 24 & 32 & 29 & 28 & 25 & $26 \cdot 8$ & $(23 \cdot 2)$ \\
\hline
\end{tabular}


Table 15 Number of notified cases of gonorrhoea and non-specific urethritis from different sources

\begin{tabular}{|c|c|c|c|c|c|c|c|}
\hline & \multicolumn{2}{|c|}{ Country } & \multicolumn{2}{|c|}{$V D C C$} & \multicolumn{2}{|c|}{ Metropolitan } & \multirow[b]{2}{*}{ Total (1977) } \\
\hline & 1976 & 1977 & 1976 & 1977 & 1976 & 1977 & \\
\hline \multicolumn{8}{|l|}{ Gonorrhoea } \\
\hline Male cases & & 133 & 589 & 681 & & 1095 & 1228 \\
\hline Female cases & & 50 & & 421 & & 643 & 693 \\
\hline Total & & 183 & & 1102 & & 1738 & 1921 \\
\hline Non-specific urethritis & & & 1206 & 1375 & & & \\
\hline
\end{tabular}

